\title{
Adolescent Childbearing in Nicaragua: A Quantitative Assessment of Associated Factors
}

\begin{abstract}
CONTEXT: Nicaragua has one of the highest adolescent fertility rates in the world, but little is known about why approximately half of Nicaraguan women give birth before age 20.

METHODS: Data from the 2001 Nicaragua Demographic and Health Survey were used to examine the sexual and reproductive behavior of 3,142 females aged 15-19. Age at sexual debut and age at first birth were assessed using life table analysis, and the impacts of various factors on these measures were then examined in Cox proportional hazard models. Among sexually active females, current use of modern contraceptives was examined using logistic regression analysis.
\end{abstract}

RESULTS: In Cox models, rural residence, rising levels of education and greater wealth were associated with older age at sexual debut (hazard ratios, 0.8, 0.5 and 0.9, respectively). When these factors were accounted for in multivariate analysis, age at first birth was positively associated with age at first sex: Having had first sex before age 15 was associated with an increased risk of having an earlier first birth (1.7-2.4), whereas having first had sex at age 16 or later was associated with a decreased risk (0.2-0.7). Among sexually active females, current use of a modern method was positively associated with being married or in a stable union and with having given birth (5.8 and 4.5, respectively), and negatively associated with lacking health care autonomy and wanting a baby within two years (0.4 and 0.6, respectively).

CONCLUSIONS: Interventions that improve young women's education and economic opportunities might help them delay both sexual debut and childbearing, and efforts are also needed to facilitate their access to contraceptives, particularly for unmarried women.

International Perspectives on Sexual and Reproductive Health, 2009, 35(2):91-96
By Katherine $C$. Lion, Ndola Prata and Chris Stewart

Katherine C. Lion is resident physician, Department of Pediatrics, University of Washington, Seattle, WA, USA. Ndola Prata is assistant adjunct professor, Bixby Program in Population, Family Planning and Maternal Health, School of Public Health, University of California, Berkeley, CA, USA Chris Stewart is assistant clinical professor, Department of Pediatrics, University of California, San Francisco, CA, USA.
Every year, 13 million babies are born to adolescent mothers between the ages of 15 and 19, representing more than $10 \%$ of total births worldwide. ${ }^{1}$ The consequences of adolescent childbearing are well established in the literature, and include higher risks of pregnancy complications and maternal mortality, increased rates of infant mortality and malnutrition, higher overall parity and more closely spaced births. ${ }^{2,3}$ Adolescent mothers are also at elevated risk of poverty, downward social mobility, and divorce or separation. ${ }^{1,4}$

Total fertility rates decreased by 19\% between 1990 and 2000 in Latin America, but adolescent fertility rates have not declined proportionately. ${ }^{1,5}$ In Nicaragua, the contrast between the rates is particularly striking: Between 1990 and 2005 , the country's total fertility rate dropped by $26 \%$, from 5.1 to 3.8 lifetime births per woman aged $15-49,{ }^{2}$ but over the same period, the adolescent fertility rate declined by only $11 \%$, from 152 to 135 births per 1,000 females aged 15-19. ${ }^{1}$ Moreover, Nicaragua's adolescent fertility rate is the highest in the world outside of Africa, and is higher than the rate for Sub-Saharan Africa as a whole (127 births per 1,000). ${ }^{1,6}$ Approximately half of young women in Nicaragua give birth before they reach age 20, and nearly a quarter of all births in the country are to adolescent women. ${ }^{7}$

\section{BACKGROUND}

Nicaragua has a unique social and political climate that likely contributes to its high adolescent fertility rate. It is the second poorest country in the Western Hemisphere, with $48 \%$ of the population living below the national poverty line. ${ }^{8,9}$ The Catholic Church continues to wield powerful influence in the country: Abortion is illegal, without any exception for the life of the mother; premarital sex is widely considered to be a sin; there is no formal sex education in Nicaraguan schools; and pregnant girls can be summarily expelled from school. ${ }^{10}$ The national health plan developed by the Nicaraguan Ministry of Health acknowledges that adolescent pregnancy is a substantial problem, but it does not address solutions. ${ }^{3}$ As a result, current efforts to reduce the rate of adolescent pregnancy tend to be small in scale, inconsistently funded and poorly supported by the government.

The cultural milieu surrounding sex and childbearing in Nicaragua is colored by machismo and marital instability. Traditionally, Nicaraguan men have sought to prove their virility by fathering numerous children, without any societal expectation that they will support those children or the children's mother. ${ }^{10}$ There has also been a trend toward informal unions instead of marriage, as well as an in- 
TABLE 1. Selected characteristics of females aged 15-19, by sexual activity and childbearing, Nicaragua, 2001

\begin{tabular}{|c|c|c|c|}
\hline Characteristic & $\begin{array}{l}\text { All } \\
(\mathrm{N}=3,142)\end{array}$ & $\begin{array}{l}\text { Sexually } \\
\text { active } \\
(\mathrm{N}=1,119)\end{array}$ & $\begin{array}{l}\text { Have given } \\
\text { birth } \\
(\mathrm{N}=667)\end{array}$ \\
\hline \multicolumn{4}{|l|}{ MEAN/MEDIANS } \\
\hline Age (mean) & 16.9 & 17.6 & 17.8 \\
\hline \multicolumn{3}{|l|}{ Age at sexual debut } & 15.5 \\
\hline Age at first birth (median) & 19.6 & 17.4 & 16.8 \\
\hline \multicolumn{4}{|l|}{ PERCENTAGES } \\
\hline \multicolumn{4}{|l|}{ Residence } \\
\hline Urban & 62 & 55 & 53 \\
\hline Rural & 38 & 45 & 47 \\
\hline \multicolumn{4}{|l|}{ Education } \\
\hline None & 6 & 11 & 12 \\
\hline Primary & 40 & 51 & 53 \\
\hline Secondary & 51 & 37 & 35 \\
\hline Higher & 3 & 1 & $<1$ \\
\hline \multicolumn{4}{|l|}{ Marital status } \\
\hline Unmarried, no partner & 70 & 1 & 9 \\
\hline Partnered, living separately & 8 & 23 & 21 \\
\hline Unmarried, cohabiting & 17 & 49 & 53 \\
\hline Married & 5 & 15 & 17 \\
\hline \multicolumn{4}{|l|}{ Aware of } \\
\hline Contraceptive methods & 96 & 98 & 98 \\
\hline Ovulatory cycle & 11 & 12 & 12 \\
\hline Has had sexual intercourse & 35 & 100 & 100 \\
\hline Has given birth & 25 & 71 & 100 \\
\hline \multicolumn{4}{|l|}{ Has used a modern method $\dagger$} \\
\hline Ever-use & na & 68 & 70 \\
\hline Current use & na & 40 & 44 \\
\hline
\end{tabular}

tIncludes hormonal and barrier methods, as well as sterilization and the IUD.

Note: na=not applicable.

creasing rate of union dissolution and divorce, which may contribute to the high adolescent fertility rate as young women try to cement their union by having a child. ${ }^{10,11}$

Yet despite the high adolescent fertility rate, contraceptive use among teenagers and young adults in Nicaragua is fairly high: Seventy percent of sexually active women aged 15-24 reported currently using a contraceptive in one large survey. ${ }^{12}$ However, other studies have found far lower rates of method use when asking about individual encounters, suggesting inconsistent contraceptive use, and the behaviors of young adults (20-24) may also be obscuring those of adolescents (15-19). ${ }^{13}$ In 2001, only 3\% of Nicaraguans aged 15-49 reported using condoms, which is particularly relevant when considering adolescent health, as adolescents are less likely to use other, continuous forms of birth control and are more likely to engage in infrequent or unplanned sex. ${ }^{14}$

Previously identified factors that were associated with

*The wealth index includes information on housing and services (e.g., type of lodging, land or home ownership, building materials, number of bedrooms, type of cooking fuel, lighting and water sources, presence of a toilet or latrine) and household possessions (e.g., mosquito net, radio, television, refrigerator, washing machine, computer, car, motorcycle, bicycle, boat, pack animal). earlier initiation of childbearing include low educational attainment, absence of the biological father from the house during childhood and living in a rural area. ${ }^{4,11}$ Recent work in Nicaragua's capital city targeting poor, urban young women demonstrated that providing vouchers for reproductive health care increased their use of contraceptives, suggesting that access may be a central issue for some groups. ${ }^{15}$ Early marriage, lack of sex education, romanticism, machismo, gender double standards and religious prohibition of contraception have also been suggested as possible contributors to the country's high adolescent fertility rate. ${ }^{10,16,17}$

This study examines the sexual and reproductive behaviors of Nicaraguan adolescent females, and recommends several approaches for designing interventions. We conducted regression analyses to assess the impacts of various socioeconomic and individual factors on adolescents' age at sexual debut, age at first birth and current use of a modern contraceptive.

\section{METHODS}

This study uses data from the 2001 Nicaragua Demographic and Health Survey (DHS). Sampling was conducted with a stratified, two-stage design, and households were randomly selected from primary sampling units to produce a nationally representative probability sample. All women within a household were interviewed individually, and the full data set included 13,060 women aged 15-49. We used data from 3,142 females aged 15-19 who answered questions about their sexual activity. Each interview lasted approximately 45 minutes, and all trained, female Nicaraguan interviewers used a structured, standardized questionnaire.

Interviews collected information on respondents' age at interview, at sexual debut and at first birth (but not about circumstances surrounding the last two measures), and on their place of residence (urban or rural), education level (none, primary, secondary, or higher), marital status (unmarried and no partner, partnered and living separately, unmarried and cohabiting, and married) and awareness of various contraceptive methods and the ovulatory cycle. Respondents were also asked whether they had ever had sex, whether they had ever given birth and whether they had ever used a modern contraceptive method. Their socio-economic status was based on various housing characteristics and the possession of a number of household items ${ }^{*}$ and the resulting wealth index was used to separate the population into wealth quintiles. Finally, respondents were asked if they wanted to have a baby within two years, and if they thought they would have a problem getting permission to go to a doctor (a marker for lack of health care autonomy).

Data were analyzed with Intercooled STATA 8.0, using the appropriate DHS-assigned survey weighting. We calculated the median age at sexual debut and age at first birth using life table analysis. These measures were then examined using survival analysis techniques, in which we 
performed Cox proportional hazard modeling separately with residence, education and wealth quintile in a bivariate model, before incorporating all of these variables in a multivariate model that yielded adjusted hazard ratios. The model for age at first birth also controlled for age at sexual debut.

We evaluated current use of a modern contraceptive (hormonal and barrier methods, sterilization and the IUD) among the 1,119 sexually active respondents using dichotomous logistic regression analysis. Bivariate testing was used to determine which of the following variables should be incorporated into the multivariate model: current age, residence, education, wealth quintile, marital status, awareness of the ovulatory cycle, years since sexual debut, whether it would be a problem to get permission to see a doctor, the desire to have a child within two years and whether a woman had ever given birth. Although the question about obtaining permission to seek medical care did not distinguish between the reasons why a respondent might require such care (e.g., contraception vs. pneumonia), it does reflect the degree of decision-making power a woman feels she has regarding her health care in general, but may overestimate her power regarding sexual and reproductive health care needs.

This study was approved by the institutional review boards at the University of California, Berkeley; the University of California, San Francisco; and the National Autonomous University of Nicaragua, León.

\section{RESULTS}

\section{Sample Characteristics}

The mean age of all respondents was 16.9 years, and 62\% lived in urban areas; $40 \%$ had some primary education and $51 \%$ had at least one year of secondary education (Table 1). Twenty-two percent of respondents lived with a partner or husband (17\% and 5\%, respectively), and 96\% were aware of contraceptive methods; however, only $11 \%$ knew about the ovulatory cycle. Thirty-five percent of all respondents had ever had sexual intercourse, and 25\% had ever given birth. The median age at sexual debut was 18.9 years, while the median age at first birth was 19.6 years.

Compared with the full sample, respondents who had had sex were less likely to live in urban areas (55\%) or to have attended secondary school (37\%); in contrast, a higher proportion of sexually active females (64\%) lived with a partner or husband (49\% and 15\%, respectively), and $71 \%$ had given birth. Meanwhile, two-thirds of sexually active females had ever used a modern contraceptive, and four in 10 reported current use. Among 343 sexually active respondents who did not want to get pregnant within two years but who said they were not using a modern method, the most commonly cited reasons were that they were unmarried and not cohabiting (44\%) or had infrequent sex (38\%), followed by personal or partner opposition ( $8 \%$ ), fear of side effects (6\%), source was too far away $(2 \%)$ and did not know a source ( $1 \%$; not shown).
TABLE 2. Bivariate and multivariate hazard ratios (and 95\% confidence intervals) from Cox proportional models identifying associations between earlier age at sexual debut and selected background characteristics

\begin{tabular}{lll} 
Characteristic & $\begin{array}{l}\text { Bivariate hazard } \\
\text { ratio }\end{array}$ & $\begin{array}{l}\text { Multivariate } \\
\text { hazard ratio }\end{array}$ \\
\hline $\begin{array}{l}\text { Residence } \\
\text { Urban (ref) }\end{array}$ & 1.00 & 1.00 \\
Rural & $1.53^{* * *}(1.36-1.73)$ & $0.76^{* *}(0.65-0.89)$
\end{tabular}

\begin{tabular}{lll} 
Education & & \\
None (ref) & 1.00 & 1.00 \\
Primary & $0.70^{* * *}(0.59-0.84)$ & $0.75^{* *}(0.62-0.90)$ \\
Secondary & $0.27^{* * *}(0.22-0.33)$ & $0.32^{* * *}(0.25-0.39)$ \\
Higher & $0.13^{* * *}(0.07-0.23)$ & $0.16^{* * *}(0.08-0.30)$ \\
Wealth index & & \\
Lowest quintile (ref) & 1.00 & 1.00 \\
Each additional quintile & $0.75^{* * *}(0.72-0.79)$ & $0.86^{* * *}(0.81-0.92)$ \\
\hline${ }^{* *} \mathrm{p}<.01 .{ }^{* * *} \mathrm{p}<.001$. Notes: $\mathrm{N}=3,142$. ref=reference category.
\end{tabular}

\section{Bivariate and Multivariate Findings}

Age at sexual debut was associated with place of residence, level of education and wealth quintile in both the bivariate and multivariate models (Table 2). In the bivariate analysis, respondents who lived in a rural area had a higher risk than urban dwellers of experiencing earlier sexual debut (hazard ratio, 1.5). The direction of the association was reversed in the multivariate model, with rural respondents having a lower risk of earlier debut (0.8). Compared with respondents who reported no education, those who had higher levels of education had decreased risks of earlier sexual debut in both models: In the multivariate analysis, the risk declined from 0.8 for respondents who had some primary education to 0.3 for those with some secondary education and to 0.2 for those with higher education, with an overall hazard ratio of 0.5 across all groups. Similarly, in both models, the risk of earlier debut was negatively associated with wealth. In the multivariate analysis, the risk declined with each quintile above the lowest (0.9).

Rural respondents were at higher risk of having an earlier first birth than were urban respondents (hazard ratio, 1.6) in the bivariate analysis (not shown). Age at first birth was negatively associated with educational level; the risk of a first birth at an earlier age declined from 0.7 for respondents with primary education to 0.3 for those with secondary school-

\begin{tabular}{|c|c|}
\hline Characteristic & Multivariate hazard ratio \\
\hline \multicolumn{2}{|c|}{ Age at sexual debut } \\
\hline $10-12$ & $1.66^{*}(1.11-2.46)$ \\
\hline 13 & $2.43^{* * *}(1.88-3.14)$ \\
\hline 14 & $1.90^{* * *}(1.54-2.33)$ \\
\hline 15 (ref) & 1.00 \\
\hline 16 & $0.71^{* * *}(0.58-0.87)$ \\
\hline 17 & $0.41^{* * *}(0.31-0.52)$ \\
\hline 18 & $0.26^{* * *}(0.18-0.38)$ \\
\hline 19 & $0.17^{* * *}(0.06-0.46)$ \\
\hline
\end{tabular}


TABLE 4. Among sexually active females, bivariate and multivariate odds ratios (and $95 \%$ confidence intervals) from logistic regression analysis identifying associations between current use of a modern contraceptive method and selected background characteristics

\begin{tabular}{|c|c|c|}
\hline Characteristic & $\begin{array}{l}\text { Bivariate } \\
\text { odds ratio }\end{array}$ & $\begin{array}{l}\text { Multivariate } \\
\text { odds ratio }\end{array}$ \\
\hline \multicolumn{3}{|l|}{ Marital status } \\
\hline \multicolumn{3}{|l|}{ Unmarried, no partner } \\
\hline $\begin{array}{l}\text { Partnered/cohabiting/ } \\
\text { married }\end{array}$ & $5.13^{* * *}(2.87-9.17)$ & $5.78^{* * *}(3.10-10.77)$ \\
\hline \multicolumn{3}{|l|}{ Has given birth } \\
\hline No (ref) & 1.00 & 1.00 \\
\hline Yes & $4.33^{* * *}(3.17-5.91)$ & $4.50 * * *(3.06-6.62)$ \\
\hline \multicolumn{3}{|c|}{ Lacks health care autonomy } \\
\hline No (ref) & 1.00 & 1.00 \\
\hline Yes & $0.52^{* *}(0.33-0.82)$ & $0.41^{* *}(0.25-0.69)$ \\
\hline \multicolumn{3}{|c|}{ Wants baby within two yrs. } \\
\hline No (ref) & 1.00 & 1.00 \\
\hline Yes & $0.46^{* * *}(0.30-0.71)$ & $0.56^{*}(0.34-0.93)$ \\
\hline
\end{tabular}

ing and 0.1 for those with higher education, compared with those who had none. The association between age at first birth and wealth quintile was negative ( 0.7$)$, but the association with age at sexual debut was positive.

In the multivariate model, only age at sexual debut remained significantly associated with age at first birth, with hazard ratios essentially unchanged after adjustment for the other factors. When compared to debut at age 15 (the most common age of debut among sexually active respondents), earlier debut was associated with an increased risk of an earlier first birth (1.7-2.4), whereas later debut was associated with a decreased risk (0.2-0.7; Table 3 , page 93).

Logistic regression analysis yielded a number of associations with current use of a modern contraceptive method. Among sexually active females, older age (odds ratio, 1.2), years since sexual debut (1.1) and awareness of the ovulatory cycle (1.6) were individually associated with increased contraceptive use, but these measures lost significance after adjusting for other factors (not shown). In the multivariate model, females who were married or in a stable union were more likely than unmarried females without a partner to be using a modern method (5.8), and those who had given birth were more likely to be practicing contraception than were those who had not (4.5; Table 4). In contrast, females who lacked health care autonomy and those who wanted a baby within two years had decreased odds of reporting method use (0.4 and 0.6, respectively).

\section{DISCUSSION}

Our findings suggest that age at sexual debut was the most important contributor to early initiation of childbearing among adolescent Nicaraguan females, and that lack of health care autonomy was a strong contributor to their nonuse of modern contraceptives. However, we recognize that these data have limitations, primarily due to the social stigma associated with sexual activity in Nicaragua. Even though the median age at reported sexual debut was not particularly young, it is notable that this age was only nine months younger than the median age at first birth in this population. While that may point to a short latency period between onset of sexual activity and first pregnancy, it is at least partly attributable to underreporting of sexual activity among those who have not given birth. Similarly, underreporting likely plays a role in the fact that nearly three-quarters of females who admit to sexual activity have already given birth.

The cross-sectional nature of these data is another major limitation of the study. For example, because no information was collected about adolescents' circumstances around the time of sexual debut or first birth, we were limited to testing associations with variables that tend to stay fairly consistent over time. Even of the factors that were evaluated, we do not know how well current residence correlates with where adolescents grew up or where they were living when the event of interest occurred. These limitations of underreported and cross-sectional data are potentially significant ones, and we wish to be explicit in considering them in our interpretation of the findings.

Our results regarding age at sexual debut largely confirm the findings of other studies, with the notable exception of the association between living in a rural area and older age at debut. While the younger ages at sexual debut typically seen in rural areas have generally been considered to be related to differences in cultural norms and values, our analysis suggests that it is related to differences in educational level and economic status. ${ }^{17}$ Research in Kenya has documented earlier sexual debut among the urban poor than among their rural counterparts, ${ }^{18}$ and our results suggest that a similar phenomenon may be occurring in Nicaragua, although it is obscured in the raw data by economic and educational disparities. Cultural norms are undoubtedly at play in this relationship, but the role of the breakdown of traditional norms and social bonds in urban areas in encouraging earlier sexual activity and childbearing may be a stronger influence than the preservation of traditional norms influencing women's roles in rural areas. This social development may become increasingly important as the migration from rural to urban areas continues. ${ }^{19}$

Age at sexual debut also had a strong association with age at first birth; in the multivariate analysis, none of the factors that would be expected to influence whether sexually active adolescents got pregnant was significant once age at debut was controlled for. The problem of underreporting must again be considered: Our analysis of age at sexual debut may in fact have captured mostly females who had already begun childbearing, and those who were sexually active but successfully practicing contraception may be missing from the analysis. If that is the case, the factors of residence, education and income may have exerted an 
influence on childbearing that exceeded their influence on sexual debut, but our models were unable to differentiate between the two outcomes because of underreporting.

Our results regarding contraceptive use reinforce the idea that access plays a major role in determining use, although not in the ways typically discussed. Nearly every factor that we found to be associated with contraceptive use can be construed as a marker for social access. For example, most females who are unmarried or who have not had a baby do not have unhindered access to contraception, in spite of it being widely and cheaply available, because of the stigma associated with premarital sex and the lack of confidential services at pharmacies and clinics. Young women who do not have decision-making power over their health care needs are similarly inhibited from obtaining contraception for reasons of social hierarchy and personal autonomy. Although limited physical access, lack of education and high cost are frequently cited as reasons for low rates of contraceptive use, ${ }^{12}$ in our Nicaraguan sample, residence, education and economic status were not associated with contraceptive use once the social aspects of access were controlled for. These results highlight the importance of confidential reproductive health care, coupled with empowerment and education of all adolescents, in improving young women's health care autonomy.

\section{Conclusions}

These findings have implications for the designing and targeting of interventions. Improving adolescents' education and economic opportunities remain reasonable and powerful strategies for raising the age at sexual debut; unfortunately, these approaches require large investments of time and effort before the intended results appear. Addressing the breakdown of traditional values and social connections in urban settings is another potential approach, but it is unclear how to accomplish this. Contraceptive use appears to be largely a function of social access in this Nicaraguan population, and a better understanding of how that access is determined within different social contexts will strengthen the design and implementation of more effective interventions.

\section{REFERENCES}

1. United Nations Children's Fund (UNICEF), Fertility and Contraceptive Use, New York: UNICEF, 2006.

2. United Nations Population Fund (UNFPA), Background on Nicaragua, New York: UNFPA, 2005.

3. Ministerio de Salud Nicaragua, Plan Nacional de Salud 2004-2015, Managua, Nicaragua: Ministerio de Salud Nicaragua, 2004.

4. Zelaya E et al., Gender and social differences in adolescent sexuality and reproduction in Nicaragua, Journal of Adolescent Health, 1997, 21(1):39-46.

5. Gupta N and da Costa Leite I, Adolescent fertility behavior: trends and determinants in northeastern Brazil, International Family Planning Perspectives, 1999, 25(3):125-130.

6. UNFPA, Country Profiles for Population and Reproductive Health: Policy Development and Indicators, New York: UNFPA, 2003.

7. Blandón L et al., Early childbearing in Nicaragua: a continuing chal- lenge, In Brief, New York: Guttmacher Institute, 2006, No. 3.

8. World Bank, Nicaragua country data profile, 2007, <http://go. worldbank.org/AYRB9G1UR0>, accessed May 28, 2009.

9. World Health Organization (WHO), Adolescent Pregnancy: Issues in Adolescent Health and Development, Geneva: WHO, 2004.

10. Berglund $S$ et al., The background of adolescent pregnancies in Nicaragua: a qualitative approach, Social Science \& Medicine, 1997, 44(1):1-12.

11. Westoff CF, Trends in Marriage and Early Childbearing in Developing Countries, DHS Comparative Reports, Calverton, MD, USA: ORC Macro, 2003, No. 5.

12. Zelaya E et al., Contraceptive patterns among women and men in León, Nicaragua, Contraception, 1996, 54(6):359-365.

13. Ali MM and Cleland J, Sexual and reproductive behaviour among single women aged 15-24 in eight Latin American countries: a comparative analysis, Social Science \& Medicine, 2005, 60(6):1175-1185.

14. WHO, Joint United Nations Programme on HIV/AIDS (UNAIDS) and UNICEF, Epidemiological Fact Sheet on HIV and AIDS: Nicaragua, 2008 Update, Geneva: UNAIDS/WHO Working Group on Global HIV/AIDS and STI, 2008.

15. Meuwissen L, Gorter AC and Knottnerus AJA, Impact of accessible sexual and reproductive health care on poor and underserved adolescents in Managua, Nicaragua: a quasi-experimental intervention study, Journal of Adolescent Health, 2006, 38(1):56.e1-56.e9.

16. Rani M, Figueroa ME and Ainsle R, The psychosocial context of young adult sexual behavior in Nicaragua: looking through the gender lens, International Family Planning Perspectives, 2003, 29(4):174181

17. Remez L et al., Ensuring a Healthier Tomorrow in Central America: Protecting the Sexual and Reproductive Health of Today's Youth, New York: Guttmacher Institute, 2008

18. Dodoo F, Zulu E and Ezeh A, Urban-rural differences in the socioeconomic deprivation-sexual behavior link in Kenya, Social Science \& Medicine, 2007, 64(5):1019-1031.

19. Pan American Health Organization (PAHO), Nicaragua Country Report, Washington, DC: PAHO, 2006.

\section{RESUMEN}

Contexto: Nicaragua tiene una de las tasas de fecundidad adolescente más altas en el mundo, pero se sabe poco acerca de las razones por las que aproximadamente la mitad de las mujeres nicaragüenses dan a luz antes de los 20 años de edad.

Métodos: Se utilizó datos de la Encuesta Nicaragüense de Demografía y Salud de 2001 para examinar las conductas sexuales y reproductivas de 3,142 mujeres en edades de 15-19 años. Se evaluó la edad de debut sexual y la edad al primer nacimiento usando análisis de tablas de vida, y los impactos de varios factores en estas medidas fueron examinados en modelos de riesgo proporcional de Cox. Se examinó el uso actual de anticonceptivos modernos en mujeres sexualmente activas usando análisis de regresión logística.

Resultados: En los modelos de Cox, la residencia rural, los niveles crecientes de educación y un mayor nivel de riqueza estuvieron asociados con una mayor edad en el debut sexual ( razones de riesgo, 0.8, 0.5 y 0.9, respectivamente). Cuando estos factores fueron tomados en cuenta en análisis multivariado, la edad al primer nacimiento estuvo asociada positivamente con la edad a la primera relación sexual: el haber tenido la primera relación sexual antes de los 15 años estuvo asociada con un mayor riesgo de tener un primer nacimiento temprano (1.7-2.4), mientras que haber tenido la primera relación se- 
xual a los 16 años o después, se asoció con un menor riesgo (0.2-0.7). Entre las mujeres sexualmente activas, el uso actual de un método moderno se asoció positivamente con el hecho de estar casadas o de vivir en una unión estable y con haber dado a luz (5.8 y 4.5, respectivamente); y, se asoció negativamente con la falta de autonomía en la atención a la salud y con el hecho de desear un bebé dentro de los próximos dos años (0.4 y 0.6 , respectivamente).

Conclusiones: Las intervenciones que mejoran la educación y las oportunidades económicas de las mujeres jóvenes podrían ayudarles a retrasar tanto el debut sexual como la maternidad; y también se necesita realizar esfuerzos para facilitar su acceso a los anticonceptivos, especialmente para las mujeres solteras.

\section{RÉSUMÉ}

Contexte: Le Nicaragua présente l'un des indices de fécondité adolescente les plus élevés au monde. Les raisons pour lesquelles près de la moitié des Nicaraguayennes deviennent mères avant l'âge de 20 ans ne sont cependant guère documentées.

Méthodes: Les données de l'Enquête démographique et de santé nicaraguayenne de 2001 ont servi à examiner le comportement sexuel et génésique de 3.142 femmes âgées de 15 à 19 ans. L'âge aux premiers rapports sexuels et l'âge au premier accouchement ont été évalués par analyse des tables de mortalité. L'impact de différents facteurs sur ces mesures a ensuite été examiné dans des modèles de risques proportionnels de Cox.
Parmi les jeunes femmes sexuellement actives, la pratique courante de la contraception moderne a été évaluée par analyse de régression logistique.

Résultats: Dans les modèles de Cox, la résidence en milieu rural, les niveaux d'éducation plus élevés et ceux de richesse supérieure sont associés à un âge plus avancé au moment des premiers rapports sexuels (rapport de risques, 0,8, 0,5 et 0,9, respectivement). Compte tenu de ces facteurs dans l'analyse multivariée, l'âge au premier accouchement est associé positivement à l'âge aux premiers rapports sexuels: les premiers rapports avant l'âge de 15 ans sont associés à un risque accru de premier accouchement à un âge précoce $(1,7-2,4)$; ceux survenus à partir de l'âge de 16 ans sont associés à un moindre risque $(0,2-0,7)$. Parmi les jeunes femmes sexuellement actives, la pratique courante d'une méthode contraceptive moderne est associée positivement au fait d'être mariée ou en union stable et à celui d'avoir déjà accouché (5,8 et 4,5, respectivement) et négativement à l'absence d'autonomie en matière de soins de santé et au désir d'avoir un enfant durant les deux années suivantes (0,4 et 0,6, respectivement).

Conclusions: Les interventions visant à améliorer l'éducation et les perspectives économiques des jeunes femmes pourraient les aider à différer leurs premiers rapports sexuels comme leur première maternité. Il est également nécessaire de faciliter l'accès des jeunes femmes, surtout célibataires, à la contraception.

Author contact: casey.lion@gmail.com 